\title{
"Ensuring of the socio-economic development of regions of Ukraine on the basis of methods of indicative planning"
}

\begin{tabular}{|c|c|}
\hline AUTHORS & $\begin{array}{l}\text { Viktoriia Klochkovska } \\
\text { Olha Khaietska https://orcid.org/0000-0002-0262-1455 } \\
\text { Antonina Broyaka }\end{array}$ \\
\hline ARTICLE INFO & $\begin{array}{l}\text { Viktoriia Klochkovska, Olha Khaietska and Antonina Broyaka (2017). Ensuring of } \\
\text { the socio-economic development of regions of Ukraine on the basis of methods } \\
\text { of indicative planning. Problems and Perspectives in Management, 15(4), 62-71. } \\
\text { doi:10.21511/ppm.15(4).2017.06 }\end{array}$ \\
\hline DOI & http://dx.doi.org/10.21511/ppm.15(4).2017.06 \\
\hline RELEASED ON & Tuesday, 19 December 2017 \\
\hline RECEIVED ON & Monday, 02 October 2017 \\
\hline ACCEPTED ON & Thursday, 16 November 2017 \\
\hline LICENSE & $\begin{array}{l}(c) \text { EY-NG } \\
\text { This work is licensed under a Creative Commons Attribution-NonCommercial } 4.0 \\
\text { International License }\end{array}$ \\
\hline JOURNAL & "Problems and Perspectives in Management" \\
\hline ISSN PRINT & $1727-7051$ \\
\hline ISSN ONLINE & $1810-5467$ \\
\hline PUBLISHER & LLC "Consulting Publishing Company "Business Perspectives" \\
\hline FOUNDER & LLC "Consulting Publishing Company "Business Perspectives" \\
\hline
\end{tabular}

NUMBER OF REFERENCES

21

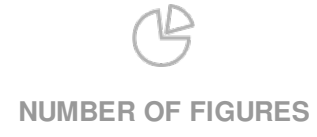

2
NUMBER OF TABLES

0

(C) The author(s) 2022. This publication is an open access article. 


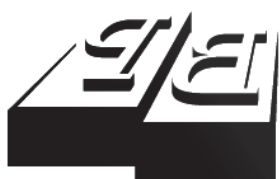

BUSINESS PERSPECTIVES

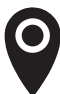

LLC "CPC "Business Perspectives" Hryhorii Skovoroda lane, 10, Sumy, 40022, Ukraine

www.businessperspectives.org

Received on: $2^{\text {nd }}$ of October, 2017 Accepted on: $16^{\text {th }}$ of November, 2017

(C) Viktoriia Klochkovska, Olha Khaietska, Antonina Broyaka, 2017

Viktoriia Klochkovska, Ph.D. in Economics, Vasyl' Stus Donetsk National University, Vinnitsa, Ukraine.

Olha Khaietska, Ph.D. in Economics, Vinnitsa National Agrarian University, Ukraine.

Antonina Broyaka, Ph.D. in Economics, Vinnitsa National Agrarian University, Ukraine.

\section{(ㄷ)(1) $(8)$}

This is an Open Access article, distributed under the terms of the Creative Commons Attribution-NonCommercial 4.0 International license, which permits re-use, distribution, and reproduction, provided the materials aren't used for commercial purposes and the original work is properly cited.
Viktoriia Klochkovska (Ukraine), Olha Khaietska (Ukraine),

Antonina Broyaka (Ukraine)

\section{ENSURING OF THE SOCIO- ECONOMIC DEVELOPMENT OF REGIONS OF UKRAINE ON THE BASIS OF METHODS OF INDICATIVE PLANNING}

\begin{abstract}
The development of the world economy is accompanied by the emergence of new causal relationships that shape the conditions and determine the features of the economic development of the regions of Ukraine in a complex and changing environment. Modern economic development requires searching for new effective means of planning to increase the level of welfare as the basis for the socio-economic development of the state as a whole. To solve this problem, indicative planning methods can be used. The purpose of the study is to develop the directions of indicative planning to ensure the socio-economic development of the regions of Ukraine in the conditions of economic transformations. The object of research is the process of socio-economic development of the regions of Ukraine, which is based on the use indicative planning methods. Planning of social and economic development in the dynamic conditions of structural and organizational transformations of the national economy, starting the investment and innovation activity is an actual, complex and multifaceted problem. For its effective solution, it is necessary to use effective means of economic appraisal of expediency, effectiveness and risks of socio-economic transformations, as well as appropriate means of planning, which should include indicative planning. The use of indicative planning is an adequate means of establishing substantiated guidelines for balanced socio-economic development at the macro level. Usage of the indicative planning system in general is decided according to the principle: the market - as much as possible, the plan - as needed.
\end{abstract}

Keywords

JEL Classification indicative plan, economic systems, development, region, stability, Ukraine

O11, O20, R58

\section{INTRODUCTION}

Today Ukraine's national economy integrates into a global economy in which there is a tough competition for limited financial resources and markets. In order to achieve success in this struggle, active cooperation between all branches of power and society in the direction of determining the national priorities, prospects and directions of development, as well as the search for the most effective ways of their implementation, is required. The necessity and urgency of the research of the national economy in the aspect of its planning and regulation are due to the fact that in the course of market transformations, there was an underestimation of the process of regulation of the economy and, as a result, inadequate to the potential use of the state regulatory system. This emphasizes the importance of this problem, which corresponds to the theoretical-methodological and conceptual-terminological concept of regulation of the economic system. The meth- 
odological, theoretical and applied significance of solving this problem is to justify the mechanism of functioning of the modern economic system with the use of indicative planning and regulation as the most important conditions for the progressive development of a mixed economy, which are a guideline and a prospect of Ukraine's development.

Indicative planning and regulation of the modern economic system is a relatively new object of analysis. The complexity of the problem is determined by methodological differences in solving the issue of the relationship between planning and regulation of the economy, as well as the possibility and reality of solving this problem by means of economic theory. The idea of the indicative planning is that the government influences economic development more quickly through coordination and information than through policy decisions and issuing guidelines.

\section{ANALYSIS OF RECENT RESEARCH AND PUBLICATIONS}

At the present stage, in the scientific literature, there are several approaches to the definition of "indicative planning":

- indicative planning is the state planning while maintaining the independence of enterprises (this definition is based on Chinese experience) (Mihasuk, 2000);

- indicative planning is the information orientation of private enterprises and encourages them to fulfil the tasks formulated be the state (this approach was widespread in Japan) (Shiyan, 2008);

- the indicative plan contains obligatory tasks for state enterprises in the form of government orders, limits, etc., and private enterprises are forced to adapt to the actions of the state (Mihasuk, 2000);

- indicative plan is a mechanism for the equal cooperation of state institutions and economic entities (this type of planning was characteristic of French practice) (Mihasuk, 2000; Shiyan, 2008).

The essence of indicative planning and its methodology was investigated in the work of Dudkin (1997), the role of indicative planning in implementing the economic strategy of the exit of Western European countries, in particular France, from the economic crisis of the postwar period, was investigated in the works of Polterovich (2006), foreign experience of indicative planning is described in the publication by Tymoschuk (2005), and the study of the stability of economic systems of various levels was described in the writings of Kozlovsky (2010, 2013).

According to Markova and Kuznetsova (2015), "the idea of the indicative planning is an important factor in ensuring economic growth, improving the economics structure, are the leading tools for optimizing economic development at the state and other levels of government".

Greenberg (2006) believes that planning "can only be indicative", while indicative planning in its interpretation is understood as "market-oriented". Obviously, such an approach leads to the preservation of classical and market economy laws, because it reduces the role and importance of the plan, placing the market at the forefront of socioeconomic development.

Tymoshchuk (2013) believes that "indicative planning is a process of forming a system of indicators that characterizes the state and development of the country's economy and corresponds to the state social and economic policy in developing measures of state influence on social and economic processes to achieve the mentioned indicators". Indicative planning is based on the establishment of government priorities, the coordination of activities of economic entities and the indirect motivation of their activities in achieving the goals set by the state using economic instruments. The benefits of indicative planning include the consistency of planned solutions, increased stability, control over the provision of the country with the 
minimum necessary volume of certain types of products and reducing the level of uncertainty in a market economy.

On the other hand, Polozenko (2004) says that indicative planning, in contrast to the directive one, is implemented on fundamentally new methodological and organizational principles, without interference of the authorities in the production and financial activity of enterprises, regions at all levels of government. This contributes to the development of local initiatives and allows commodity producers to respond in time to the demand that forms the structure of production. The basis of the indicative planning model is the real natural and economic conditions of the regions used by the manufacturer when making a business plan, considering the needs of the market. Marketing program, which integrates a whole range of measures to ensure price policy, optimizes the market of goods and sales, has a special weight.

Psarev (2010) proved that the formation of an indicative plan for the short and medium term is possible only if there is an approved concept and strategy for the development of an administrativeterritorial unit - a region that defines the goals and priorities for development in the long-term period, as well as a system of actions for achieving these goals. The results of theoretical studies and practical experience of strategic planning make it possible to conclude that there is a need for a hierarchical approach to the classification of goals and objectives of strategic development.

According to Yevseyeva (2011), "There is no coherent system of indicative planning in Ukraine many provisions of state regulation remain controversial. This necessitates the development of relevant principles, priorities, and the algorithm of the process of indicative planning at different levels, and accordingly, it actualizes and defines the prospects for further scientific developments in this direction".

Pogrebnyak (2005) and Yurynets (2016) note the imperfection of the institutional planning system in Ukraine and believes that such a system should be based on three elements: the first executes the management of the planning process and has administrative powers; the second provides scientific support for planning; the third is a forum for exchange of ideas and understanding of important issues.

At present, in Ukraine, the problem of using indicative planning is only discussed. So, although the academicians of the National Academy of Sciences of Ukraine Geyets, Panchenko, Libanova (2003) didn't address this problem, focusing on many issues of budget planning, the use of indicative planning methods remained open.

Noting the diversity of fundamental approaches to the disclosure of individual aspects of the subject under study, it is worth emphasizing that the theoretical and methodological aspects of indicative planning and regulation of the economic system are in demand for scientific research. Relevance, lack of theoretical and methodological development of these problems, discussion nature of individual issues determined the choice of research tasks.

\section{THE PURPOSE OF THE RESEARCH}

The purpose of this study is to develop mechanisms for indicative planning to ensure the socioeconomic development of the regions of Ukraine.

\section{MAIN RESULTS OF RESEARCH}

The scientific substantiation of the methodology of the indicative planning of the socio-economic development of the regions of Ukraine envisages the reflection of the natural, geopolitical, socioeconomic, national and cultural and other conditions of the country and ensuring unity in regional diversity under the influence of the processes of globalization. The peculiarity of modern regional problems in Ukraine is determined by the interweaving of a number of complex transitional processes: people.

The scientific substantiation of the methodology of the indicative planning of the socio-economic development of the regions of Ukraine envisages the reflection of the natural, geopolitical, socio- 
economic, national and cultural and other conditions of the country and ensuring unity in regional diversity under the influence of the processes of globalization. The peculiarity of modern regional problems in Ukraine is determined by the interweaving of a number of complex transitional processes: growing socio-economic differences between regions, the emergence of problem regions, complex relations between the "centre" and regions, the disintegration of the economic space. Implementation of the strategy of territorial development of the country requires not only the intensification of regional policy, but also the improvement of legal, institutional, economic mechanisms of state relations.

The most important aspects of the modernization of the Ukrainian economy and its sustainable development (Kozlovskyi, 2013) are the support of the necessary territorial proportions in the economy, prevention of excessive differentiation of regions in terms of socio-economic development, ensuring the effective functioning of the Ukrainian market.

In scientific research, Ansoff (1999) emphasizes "that only centralized-directive planning, and not indicative planning or programming of the economy, is incompatible with the market". Meanwhile, some domestic economists, in principle, without rejecting this thesis, deny the possibility of using indicative plans in modern Ukrainian conditions, referring to the underdevelopment of the institutional system of the Ukrainian economy. However, the latter can serve as proof rather than "against", and "for" the rapid establishment of a system of indicative planning, which is designed to provide at least a minimum level of consistency in the activities of business entities.

Often, under indicative planning, they understand the way of regulating economic processes by setting a certain goal of socio-economic development and creating state financial and other incentives for those enterprises that agree to act in accordance with state recommendations (Kozlovskyi, 2013).

Accordingly, indicative planning should be characterized as a mechanism for coordinating state and non-state actors of economic management, which combines state regulation of the economy and market self-regulation, which is based on the development of a set of indicators (indicators of socio-economic development).

The indicative plan contains two parts: indicative and legislative. In particular, in the indicative part, the state authorities determine the priority economic goals, variants of prediction of structural changes, scientific and technological progress, dynamics of key positions in terms of availability and use of material and financial resources, changes in the conjuncture of domestic and foreign markets, price levels and ratios on the basis of analysis of the functioning of the economy. The legislative part of the indicative plan contains a budget plan, the characteristics of the tax system, the bank interest rate, depreciation rates, and the development of a public procurement. The following are the most commonly used methods of indicative planning characterization: forecasts and perspective plans for socio-economic development; comprehensive target programs for solving problem situations; construction of forecasts of the state of affairs and dynamics of development of internal and external markets (Shvedun, 2016).

The most important object of indicative planning in Ukraine is the regions. The experience of implementing market reforms at the level of Ukrainian regions shows that one of the effective instruments of state regulation of the region's economy should be indicative planning, methodology, technology and organization of which should be built in accordance with market relations. The indicative planning system in the region should meet the following requirements (Kozlovskyi, 2010):

- firstly, the indicative plan for the development of the region should reflect the functions of the regional executive authorities;

- secondly, the indicative plan for the region's development should form the basis for the development of a regional budget;

- thirdly, the indicative plan for the region's development should contain information of interest to entrepreneurs and potential investors in terms of the level of socio-economic development of the region, the benefits of the eco- 


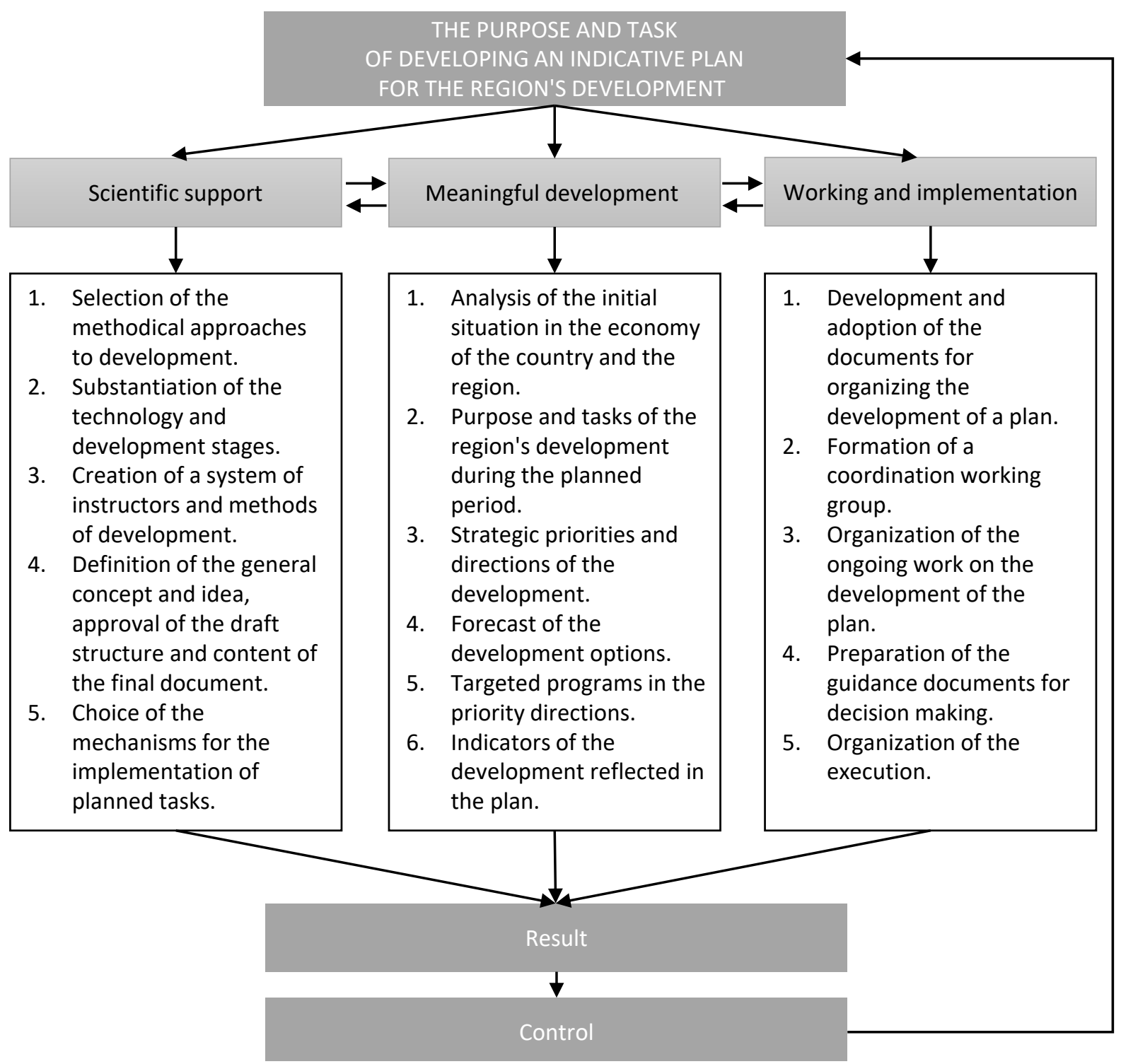

Figure 1. The structure of the development of the indicative plan for the region's development

nomic policy of regional authorities and the factors determining the investment climate;

- fourth, in the indicative plan for the region's development, it should reflect the continuity and linkage with the long-term strategy of socio-economic development of the region.

Indicative planning is the main working tool for implementing strategic development plans, taking into account the specific economic situation. The indicative plan includes conceptual (the concept of socio-economic development), forecast (forecast of socio-economic development), planning and regulating part (system of economic regulators and state target integrated programs).
For Ukraine, due to the specifics of its political and socio-economic development, it is the most expedient to use the strategic form of indicative planning.

The strategic form of indicative planning involves the development of a strategic plan, structured per year, five years and a 15-years period, at the regional level. In the conditions of the modern information society for the subjects of economic activity, state and society as a whole, it is particularly necessary to scientifically substantiate the prediction of future trends of scientific and technical and socio-economic development. In this regard, it should be noted that for normal activities of most sectors of the economy, at least a 5 -year perspective is required. 
The main function of the indicative plan for the socio-economic development of the region is the substantiation and development of methods and methods of the state-controlled influence on the future trajectory of the development of the regions. In the technology of developing an indicative plan, the extrapolation of past trends should not prevail. The primary task is to break down the negative trends that have emerged in socio-economic development and to stimulate economic growth.

The development of an indicative plan should begin with the formulation of the goals of socio-economic development of the region for a given perspective and the assessment of available resources that can be used to implement these goals.

The general scheme of the healthcare of the phased development of the regional indicative plan, proposed by Kozlovskyi (2017) and supplemented with such elements as control and feedback mechanism (see Figure 1).

Objects of indicative planning in the region are:

- production sphere (industry, agriculture, construction);

- infrastructure complex (transport and communications, roads, power networks, heat, water, electricity);

- social sphere (education, culture, healthcare, housing and communal services);

- markets (commodity markets, stock markets, services market, real estate);

- territorial objects (territories of districts, cities, settlements, economic entities of different forms of ownership).

The basis of the detailed development of the region is the system of the needs, which is divided into two large blocks. This is a system of needs of the population, on the one hand, and, on the other hand the social production of the region. If the system of human needs is due to its biological and social nature, then the need for social production is determined by the need for its sustainability, recovery and efficiency. As a result, there are planned ways to improve the structure of production, the solution of social problems, the implementation of foreign economic policy, environmental protection, and so on.

In the indicative planning of the development of the region, the coordination of the interests of the subjects, participants are to choose the main directions of development of economic entities, mutually acceptable to all participants in the economic activity. In the process of coordinating the interests of participants in regional development, external conditions for the realization of the goals formed by external markets, the interaction of the region with the centre and other regions, and the natural environment should be taken into account.

The system of priorities involves the concentration of resources in certain areas in relation to the implementation of program objectives. However, such an approach should not undermine the comprehensive balance of the region's economy. In accordance with the system-wide principles of sustainable development, the patterns of scientific and technological progress, as well as the characteristics of the economy of the region under study, the priorities should be directed at strengthening of a number of its properties: flexibility (adaptation to changing conditions); efficiency (realization of competitive advantages of the region); progressiveness (compliance with advanced technologies); environmental friendliness (environmental protection); humanism (development of cultural and intellectual potential of man).

The development of an indicative plan for the socioeconomic development of the region is closely connected with the construction of the concept of development that precedes it, embodied in the strategy. The development of an indicative regional plan is as close as possible to forecasting, which is rightly considered as a component of indicative planning (Lyulyov \& Shvindina, 2017).

The analysis of the socio-economic situation in the region serves as the main content of the pre-planning stage, the establishment of trends that are reflected in the indicative planning. Assessment of the achieved level of development of the region makes it possible to determine the potential of the region, the degree of its involvement in production, to identify unresolved problems. It is expedient to carry out the 
strategic analysis of the development of the region in two main stages: 1) a retrospective analysis and ast sessment of the current state of socio-economic development of the region; 2) development of forecasts for the development of a regional economy.

At the first stage of strategic analysis, it is expedient to use the relevant information of statistical bodies, materials of the branch, public and other institutions and organizations. The main purpose of this stage of strategic analysis is to assess the effectiveness of the region's development strategy in the past period.

The second stage of carrying out a strategic analysis of the region's development is related to the definition of the permissible range of possible options for the development of the regional system with a view to adopting the optimal solution.

The forecast of socio-economic development of the region or regional forecast is a set of substantiated assumptions, expressed in qualitative and quantitative forms, giving an idea of the future parameters of the region's development. The basis of regional forecasting is the assumption that the future state of the regional system is largely determined by its past and present status.

An integral feature of regional forecasting is a proactive reflection of reality, that is, the adaptation of the economic system to the future. Such a reflection makes it possible to solve the contradiction between the initial conditions and the given development trajectory. Moreover, the range of permissible trajectories of the region's development and the possibility of a proactive reflection of reality, depending on the time horizon of the forecast, are changing. With the expansion of the prediction horizon, an appropriate expansion of the field of permissible development trajectories occurs.

The indicative plan should be balanced, this is the most important condition for the sustainable economic development of the region, and it requires the identification of regularities characteristic of both the socio-economic system as a whole and its individual components. For the dynamic development of the regional socio-economic system, not only should we maintain the proportionality between the individual links, but also combine the changes of the most different proportions that are in the structure of the economy. Only such a balance will ensure the transition of the economy of the region to a higher quality level.

An integral part of the process of forming a system of indicators for an indicative plan for the region's development is the establishment of the threshold values of these indicators. Thresholds are quantitative indicators that numerically reflect the maximum permissible values from the standpoint of economic interests of the development of both the region and economic entities, the failure to comply with them can lead to undesirable processes in the economy, primarily disproportions. The level of threshold values is set in the course of forecast-analytical developments. An indispensable part of the regional indicative plan are indicators of targeted programs to address the most important socio-economic problems and the placement of government orders.

Methods and models of analytical work used in the preplanned stages of indicative planning are statistical methods for processing dynamic series, regression and correlation analysis, index method, methods for calculating market concentration coefficients. In developing the indicative plan, methods of justification of goals, program-target methods, methods of decision-making are used. The complexity and multi-stage development of an indicative plan for the development of the region make it difficult to find universal methods, so it is necessary to systematically use methods and models at various stages, adequately describing the process of functioning of planning objects that meet the goals and objectives of the analysis and synthesis of planned problems.

The combination of methods and models is implemented within the framework of a technological scheme for the development of an indicative plan for the socio-economic development of the region (Figure 2).

The main purpose of indicative planning of socioeconomic development is the formation and implementation of a complex of analytical and forecast documents, plans and programs that provide coordinated activities of all participants in the planning process. It is aimed at achieving the goals and objectives of the region, creating favorable conditions for the life and activities of all business and social objects, sustainable and safe development of society. 


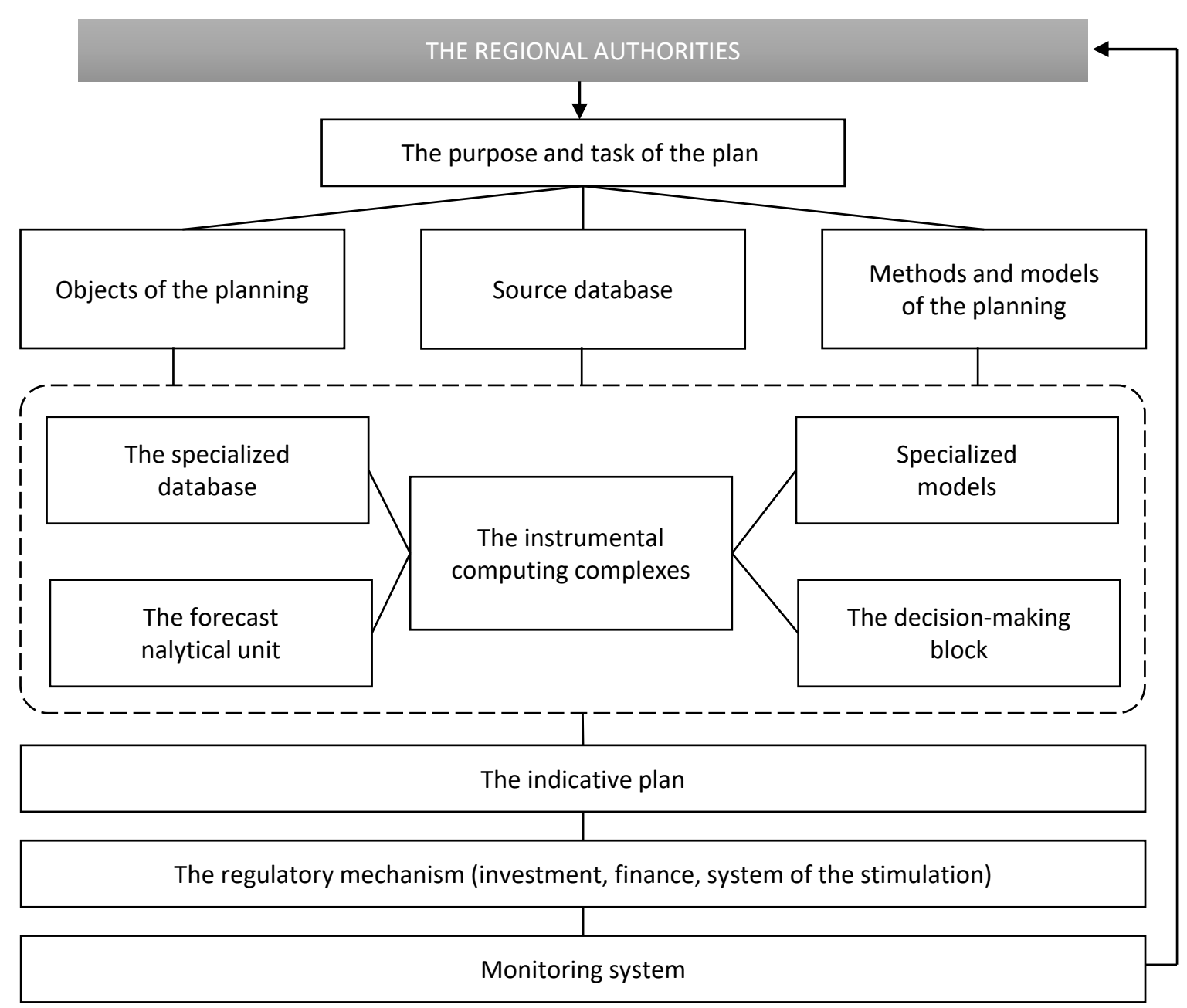

Figure 2. Technology and methods of developing an indicative plan for the region's development

\section{CONCLUSION}

Consequently, indicative planning is an effective mechanism for realization of the strategic goals of the development of regions of Ukraine, which is intended to address the priority issues of the regions, promote the growth of living standards and the efficiency of regional governance. Further improvement of theoretical and methodological foundations of the formation of institutional and legal support, mechanisms of regulation and interaction between the subjects of the planning process, the implementation of modern methods of monitoring and programming are necessary. The indicative plan outlines the main goals and objectives of regional development in the medium and short-term periods. It is the basis for the development of economic programs. The quality of the indicative plan depends primarily on the professional level of the team of developers, the activity of the stakeholders involved in the planning process (government, business, and population), which contributes to the consensus of interests of all parties and the improvement of the effectiveness of planning and management. It is necessary to create a unified regional monitoring information system designed to improve the quality of the analysis, evaluation, forecast and unified plan process. Indicative planning successes are impossible without the effective use of organizational, financial, economic, administrative, institutional, regulatory and information mechanisms for the implementation of indicative plans for regional development. 
The requirements for the system of regional strategic indicative planning are formulated taking into account the elements of state regulation, which consists in the fact that the indicative plan for the development of the region should be formed on the existing powers of the regional authorities; form the basis for the development of the regional budget; contain information of interest to entrepreneurs and potential investors in terms of determining the direction of socio-economic development of the region, the benefits of economic policy of regional authorities, factors affecting the investment climate, etc.

Thus, it was found that indicative planning is a process of forming a system of indicators that reflect the state of socio-economic development of the region's economy. Implementation of the regional management of indicative planning system in practice is an instrument for realizing the strategic goals of socioeconomic development of the regions of Ukraine.

\section{REFERENCES}

1. Ansoff, I. (1965). Corporage Strategy (353 p.). Mc-Graw-Hill Inc., US.

2. Dudkin, V. (1997). Индикативное планирование: о сущности и методологическом инструментарии [Indikativnoe planirovanie: o suschnosti i metodologicheskom instrumentarii]. Rossiyskiy ekonomicheskiy zhurnal, 4, 104-106.

3. Evseeva, О. О. (2011). Методичний підхід до розробки системи індикаторів і прогнозування соціальноекономічного розвитку регіону [Metodychnyi pidkhid do rozrobky systemy indykatoriv i prohnozuvannia sotsialno-ekonomichnoho rozvytku rehionu]. Ekonomichnyi prostir, 46, 62-73.

4. Grinberg, R., Olav F. Knudsen (2006). Economic patterns and trends. Proceedings of the Conference: Russian and the New Europe: Borderlands and Integration.

5. Heiets, V. M., Panchenko, E. H., Libanova, E. M. et al. (2003). Перехідна економіка [Perekhidna ekonomika] (591 p.). Kyiv: Vyscha shkola.

6. Kozlovskyi, S. V. (2010). Методологічні основи розробки системи індикативного планування в регіоні [Metodolohichni osnovy rozrobky systemy indykatyvnoho planuvannia $\mathrm{v}$ rehioni]. Rehionalna ekonomika, 1(55), 32-38.

7. Kozlovskyi, S. V. (2010). Управління сучасними економічними системами, їх розвитком та стійкістю [Upravlinnia suchasnymy ekonomichnymy systemamy, yikh rozvytkom ta stiikistu] (432 p.). Vinnytsia: Merkuri-Podillia.

8. Kozlovskyi, S. V. (2017). Забезпечення стійкості та розвитку сучасних економічних систем [Zabezpechennia stiikosti ta rozvytku suchasnykh ekonomicnhykh system] (554 p.). Vinnytsia: TOV "Nilan-LTD".

9. Kozlovskyi, S. V., Burlaka, O. M. (2013). Індикативні методи забезпечення стійкості економіки України [Indykatyvni metody zabezpechennia stiikosti ekonomiky Ukrainy]. Efektyvna ekonomika: elektronne naukove vydannia, 10. Retrieved from http://www.economy.nayka.com. $\mathrm{ua} /$ ?op $=1 \& \mathrm{z}=2373$

10. Lyulyov, O., \& Shvindina, H. (2017). Stabilization Pentagon Model: application in the management at macro- and microlevels. Problems and Perspectives in Management, 15(3), 42-52. doi:10.21511/ppm.15(3).2017.04

11. Markova, V. D., Kuznetsova, S. А. (2015). Новые тренды в развитии теории и методов стратегического менеджмента [Novye trendy v razvitii teorii i metodov strategicheskogo menedzhmenta]. Region: ekonomika i sotsiologiya, 2, 266-285.

12. Mykhasiuk, I. R. (Ed.), Melnyk, A., Krupka, M. (2000). Державне регулювання економіки: підруч- ник [Derzhavne rehuliuvannia ekonomiky: pidruchnyk] (592 p.). Kyiv: Ataka; Elga-N.

13. Pohrebniak, M. M. (2005). Індикативне планування як основа удосконалення системи державного регулювання економіки України [Indykatyvne planuvannia yak osnova udoskonalennia systemy derzhavnoho rehuliuvannia ekonomiky Ukrainy]. In V. F. Besedin \& A. S. Muzychenko (Eds.), Ринкова трансформація економіки України: проблеми регулювання [Rynkova transformatsiia ekonomiky Ukrainy: problemy rehuliuvannia] (pp. 141-145). Kyiv: NDEI.

14. Polozenko, D. V. (2004). Планування в системі державного регулюванні економіки і ринкового саморегулювання [Planuvannia v systemi derzhavnoho rehuliuvannia ekonomiky i rynkovoho samorehuliuvannia]. Statystyka Ukrainy, 4, 57-60.

15. Polterovich, V. (2006). Эволюционная теория экономической политики. Часть I. Опыт быстрого развития [Evolutsionnaya teoriya ekonomicheskoi politiki. Chast I. Opyt bystrogo razvitiya]. Voprosy ekonomiki, 7, 4-23.

16. Psarev, V. I., Suschentseva, N. V. (Eds.), Psareva, N. V., Goncharov, I. А. (2010). Методика формирования и анализа комплексных программ социально-экономического развития муниципальных образований [Metodika 
formirovaniya i analiza kompleksnykh program sotsialno-ekonomicheskogo razvitiya munitsipalnykh obrazovaniy] (511 p.). Novosibirsk.

17. Shvedun, V. O. (2016). Специфіка використання індикативного планування в механізмі практичного впровадження концепції державного регулювання в сфері рекламної діяльності [Spetsyfika vykorystannia indykatyvnoho planuvannia v mekhanizmi praktychnoho vprovadzhennia kontseptsii derzhavnoho rehuliuvannia $\mathrm{v}$ sferi reklamnoi diialnosti]. Investytsii: praktyka ta dosvid, 9, 101-103.
18. Shyian, N. I. (2008). Державне регулювання економіки: навч. посіб. для студ. екон. спец. [Derzhavne rehuliuvannia ekonomiky: navch. posib. dlia stud. ekon. spets.] (383 p.). Kharkiv: Format Plus.

19. Tymoschuk, M. (2005). Індикативне планування: зарубіжний досвід та перспективи застосування в Україні [Indykatyvne planuvannia: zarubizhnyi dosvid ta perspektyvy zastosuvannia $\mathrm{v}$ Ukraini]. Rehionalna ekonomika, 3, 230-236.

20. Tymoschuk, M. R. (2013). Концептуальні засади планування соціально-економічного розвитку підприємств [Kontseptualni zasady planuvannia sotsialnoekonomichnoho rozvytku pidpryiemstv]. Proceedings of the VI International scientific and practical conference (Kharkiv, October 30-31, 2013), 273-275. Kharkiv: Vyd. tsentr NTU “KHPI".

21. Yurynets, Z. (2016). Forecasting model and assessment of the innovative and scientific-technical policy of Ukraine in the sphere of innovative economy formation. Investment Management and Financial Innovations, 13(2). doi:10.21511/imfi.13(2).2016.0 